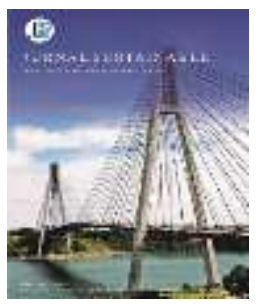

\title{
Perancangan Perangkat Pengering Ikan Otomatis Skala Mini
}

\author{
Rozeff Pramana ${ }^{1}$, Kharisma Ilham $^{2}$, Sapta Nugraha ${ }^{3}$, Muhamad Otong $^{4}$, Didik Aribowo ${ }^{5}$ \\ ${ }^{1,2,3}$ Jurusan Teknik Elektro, Fakultas Teknik, Universitas Maritim Raja Ali Haji \\ ${ }^{4}$ Jurusan Teknik Elektro, Fakultas Teknik, Universitas Sultan Ageng Tirtayasa \\ ${ }^{5}$ Jurusan Pendidikan Teknik Elektro, Fakultas Keguruan \& Ilmu Pendidikan, Universitas Sultan \\ Ageng Tirtayasa \\ *Corresponding Author: rozeff@umrah.ac.id
}

\begin{abstract}
Water content is the percentage of water content contained in the material and expressed in units of per cent. It can affect the texture of fish and cause the development of bacteria in fish. In general, people only know the process of drying fish by looking at the texture of the fish while the water content found in fish is in accordance with the Indonesian National Standard (SNI), which is $40 \%$. The purpose of drying fish is by controlling the water content so that the fish can be dried in accordance with the Indonesian National Standard (SNI). This device uses a DS18B20 temperature sensor, load cell sensor, relay, heating element, and cooling fan. The working principle of this device uses a heating element to reduce the water content or load on the fish and the cooling fan to remove the hot temperature from the cabinet which is controlled by a relay to regulate the temperature. The heater will be active when the temperature is less than $60^{\circ} \mathrm{C}$ and the cooling fan is not active when the temperature is more than $60^{\circ} \mathrm{C}$. The device will automatically stop the heater when the load value is smaller or equal to the value of the set point. Reduction of water content up to $40 \%$ according to the Indonesian National Standard (SNI) with a $250 \mathrm{~g}$ fish load takes 1 hour 43 minutes, a 500g fish load for 3 hours 17 minutes, and a 1000g fish load for 6 hours 25 minutes.
\end{abstract}

Keywords - Arduino Mega 2560, DS18B20, loadcell, keypad.

Intisari-Kadar air merupakan persentase kandungan air yang terdapat pada bahan dan dinyatakan dalam satuan persen. Kadar air dapat mempengaruhi tekstur ikan dan menyebabkan adanya perkembangan bakteri pada ikan. Secara umum masyarakat hanya mengetahui proses pengeringan ikan dengan cara melihat tekstur pada ikan sedangkan kadar air yang terdapat pada ikan sesuai dengan Standar Nasional Indonesia (SNI) yaitu 40\%. Tujuan dari mengeringkan ikan dengan cara mengontrol kadar air agar ikan dapat dikeringkan sesuai dengan Standar Nasional Indonesia (SNI). Perangkat ini menggunakan sensor suhu DS18B20, sensor loadcell, relay, elemen pemanas, dan kipas pendingin. Prinsip kerja dari perangkat ini menggunakan elemen pemanas untuk mengurangi kadar air atau massa pada ikan dan kipas pendingin untuk mengeluarkan suhu panas dari kabinet yang dikontrol oleh relay untuk mengatur suhu. Pemanas akan aktif ketika suhu kurang dari $60^{\circ} \mathrm{C}$ dan kipas pendingin tidak aktif, ketika suhu lebih dari $60^{\circ} \mathrm{C}$. Perangkat akan otomatis menghentikan pemanas ketika nilai massa lebih kecil atau sama dengan nilai dari set point. Pengurangan kadar air hingga 40\% sesuai Standar Nasional Indonesia (SNI) dengan massa ikan 250g membutuhkan waktu selama 1 jam 43 menit, massa ikan 500g selama 3 jam 17 menit, dan massa ikan $1000 \mathrm{~g}$ selama 6 jam 25 menit.

Kata kunci-Arduino Mega 2560, DS18B20, loadcell, keypad. 


\section{Pendahuluan}

Pengolahan ikan yang baik dapat mengatasi kelebihan hasil produksi dan dapat mempertahankan kualitas ikan. Pengawetan ikan secara tradisional bertujuan untuk mengurangi kadar air dalam tubuh ikan. Berkurangnya kadar air yang terdapat pada ikan dapat mencegah berkembangnya bakteri [1].

Pengeringan ikan yang digunakaan saat ini oleh masyarakat masih menggunakan cara tradisional dengan menjemur ikan yang memanfaatkan panas dari sinar matahari. Secara umum masyarakat hanya mengetahui proses pengeringan ikan dengan cara melihat tekstur pada ikan [1]. Padahal, berdasarkan Standar Nasional Indonesia [2] kadar air pada ikan kering yaitu $40 \%$ dari bobot maksimalnya.

Kadar air merupakan kandungan air yang terdapat pada bahan dan dinyatakan dalam satuan persen. Kadar air dapat mempengaruhi tekstur ikan dan menyebabkan adanya perkembangan bakteri pada ikan. Teknik untuk mengurangi kadar air pada ikan menggunakan proses teknik pengeringan ikan dengan energi panas untuk mengurangi sebagian air pada ikan. Teknik pengeringan ikan untuk mengurangi kadar air dapat diatur dengan proses sistem kontrol. Sistem kontrol adalah proses pengendalian atau pengaturan pada suatu variabel dan parameter. Sistem yang akan dikontrol yaitu berat kadar air yang terdapat pada ikan. Sensor loadcell akan mengukur berat ikan untuk mengetahui kadar air pada ikan.

Berdasarkan latar belakang tersebut, maka akan dirancang sistem kontrol kadar air pada ikan berbasis mikrokontroler. Hal ini dilakukan untuk mengetahui kadar air pada ikan saat proses pengeringan terjadi. Mengontrol kadar air pada ikan dilakukan secara real time selama proses pengeringan ikan.

\section{Tinjauan Pustaka}

\section{A. Kajian Terdahulu}

Kajian terdahulu terkait judul penelitian ini sebelumnya pernah dilakukan [3]. Suhu air sangat berpengaruh pada kemampuan metabolism ikan. Penelitian ini merancang suatu perangkat yang dapat mengatur suhu untuk pendederan dan pembenihan ikan Nila. Pendederan dan pembenihan ikan nila memiliki range toleransi suhu $30^{\circ} \mathrm{C}-32^{\circ} \mathrm{C}$, penelitian ini menggunakan ATMega 328P yang terintegrasi dengan Arduino board sebagai kendali. Untuk memperoleh nilai suhu perangkat ini menggunakan thermistor yang kemudian diproses menggunakan persamaan SteinhartHart. Nilai suhu dapat diukur setiap 1 detik yang dapat dimonitor melalui perangkat lunak Visual Basic 6.0 dan disimpan dalam database menggunakan Microsoft Access. Output Kendali memiliki dua keadaan yaitu mengaktifkan heater, atau melakukan pergantian air. Heater akan aktif ketika suhu berada di bawah suhu minimum toleransi, sementara pergantian air akan aktif ketika suhu berada di atas suhu maksimum toleransi. Perangkat monitoring memiliki 2 mode yaitu mode manual dan mode auto. Hasil pengujian diperoleh sistem kendali relay untuk heater dan sirkulasi berjalan dengan baik, rata-rata penyimpangan pengukuran suhu adalah $0.273131 \%$. Penggunaan sensor suhu dan heater pada penelitian ini adalah untuk menjaga kondisi ikan sesuai dengan habitat alaminya.

Penelitian selanjutnya [4] ingin mengetahui lama pengeringan ikan selar yang dihubungkan dengan kadar air dan nilai organoleptic. Pengurangan kadar air pada ikan selar berdasarkan pada waktu yang telah diprogramkan. Penelitian ini menggunakan pengering buatan dengan lama waktu pengeringan diatur untuk waktu 4 jam, 8 jam, 12 jam, dan 16 jam dengan suhu antara $60^{\circ} \mathrm{C}-65^{\circ} \mathrm{C}$. Hasil dari penilitian didapat kadar air pada ikan selar selama 4 jam adalah $50.30 \%, 8$ jam $35.15 \%, 12$ jam 26.87\%, 16 jam 20.91\%. Ikan asin yang dikeringkan melebihi waktu 12 jam dengan suhu $60^{\circ} \mathrm{C}-65^{\circ} \mathrm{C}$ dapat diterima oleh konsumen, sedangkan ikan asin yang di keringkan kurang dari 8 jam dengan suhu $60^{\circ} \mathrm{C}$ $65^{\circ} \mathrm{C}$ kurang dapat diterima oleh konsumen.

Penelitian selanjutnya, pengeringan gabah pada cuaca yang tidak menentu membuat proses pengeringan gabah oleh petani menjadi terhambat. Penelitian ini bertujuan mempercepat waktu pengeringan gabah pada saat cuaca yang tidak menentu. Perangkat penelitian dirancang menggunakan mikrokontroler AVR Mega 16 
sebagai pengolahan data, pengatur dan pengontrol sistem kerja alat dan menggunakan BASCOM AVR sebagai perangkat lunaknya. Hasil dari pengujian kadar air resistif nilainya berbanding lurus dengan nilai tegangan yang dihasilkan. Pada pengujian suhu setiap kenaikan $1^{\circ} \mathrm{C}$ maka tegangan akan bertambah $10 \mathrm{mV}$ atau $0.01 \mathrm{~V}$ [5].

Penelitian lain mengangkat permasalahan para petani dimana untuk mengetahui kadar air pada gabah hanya yang menggunakan indera dan kebiasaan, yaitu dengan cara memotong atau menggigit gabah yang akan ditera kadar airnya. Penelitian ini bertujuan untuk mendeteksi atau mengukur kadar air pada padi dengan nilai yang tepat. Penelitian menggunakan metode rekayasa. Penelitian menggunakan mikrokontroler Mega 8 sebagai alat pemproses dan sensor suhu LM 35. Suhu yang dideteksi oleh sensor akan diubah ke bentuk nilai tegangan yang selanjutnya diproses mikrokontroler Mega 8. Hasil dari pengujian alat pengukur kadar air pada gabah memiliki tingkat kesalahan berdasarkan perbandingan alat buatan IRRI sebesar $0.38 \%$ [6].

Penelitian selanjutnya permasalahan proses pengasapan ikan yang dilakukan oleh masyarakat Kepulauan Riau masih menggunakan cara tradisional, proses tersebut membutuhkan waktu matang yang lama. Penelitian bertujuan untuk mempersingkat proses pengasapan ikan. Pada penelitian tersebut menggunakan sensor DHT22 yang berfungsi sebagai pendeteksi suhu dan kelembaban ruang kabinet, blower sebagai pengatur sirkulasi suhu pada kabinet, push button sebagai input setting, solar panel sebagai sumber tegangan mandiri, LCD sebagai interface ke pengguna, dan microcontroller sebagai pengoperasian data. Sistem kerja prototype yaitu Arduino akan mengontrol blower sebagai temperature suhu pada cabinet. Jika suhu ruang lebih dari $60^{\circ} \mathrm{C}$ blower akan aktif dan setiap 5 menit motor akan aktif yang berfungsi menyuplai serabut kedalam rak perapian. Hasil dari penelitian proses pengasapan yang dilakukan selama 3 jam suhu mencapai $64.50^{\circ} \mathrm{C}$ dan kelembaban $15.80^{\circ} \mathrm{C}$ [7].

Perancangan perangkat pengering ikan dengan pemanas berupa lampu Hologen dan memiliki sumber daya listrik mandiri berupa solar panel untuk pengeringan kadar air pada ikan berdasarkan waktu, bukan berdasarkan kadar air yang diinginkan. Sensor suhu yang digunakan DHT22 untuk mengetahui temperature suhu pada ruang cabinet dan Arduino uno sebagai mikrokontroler yang diprogram untuk menjalankan perangkat dan pengatur suhu pada cabinet. Suhu cabinet diatur apa bila suhu mencapai $50^{\circ} \mathrm{C}$ lampu halogen dan kipas pendingin akan berhenti beroperasi, apabila suhu kurang dari $45^{\circ} \mathrm{C}$ maka lampu halogen dan kipas pendingin akan beroperasi kembali untuk memanaskan ruang cabinet. Hasil dari penelitian setiap 5 menit suhu ruangan kabinet akan naik dan kelembaban pada ruang kabinet menurun. Untuk mencapai suhu yang optimal untuk pengeringan ikan yaitu $45^{\circ} \mathrm{C}$, dibutuhkan waktu 30 menit dari awal perangkat diaktifkan [8].

Berdasarkan kajian dari peneliti-peneliti sebelumnya, maka pada penelitian ini akan dirancang perangkat pengering ikan dengan mengurangi kadar air pada ikan yang dapat di atur persentasenya sesuai keinginan.

\section{B. Landasan Teori}

\section{1) Kadar Air Pada Ikan}

Kadar air adalah persentase kandungan air pada suatu bahan yang dapat dinyatakan berdasarkan berat basah (wet basis) atau berdasarkan berat kering (dry basis). Kadar air pada ikan terdapat banyak kandungan air dapat menyebabkan berkembangnya bakteri dan pembusukan pada daging ikan. Pengeringan dapat mengurangi kadar air yang terdapat pada ikan dan menjaga agar daging ikan tidak membusuk. Prinsip penentuan kadar air dengan pengeringan adalah menguapkan air yang ada pada bahan dengan cara pemanasan.

Berdasarkan Standar Nasional Indonesia [9] penentuan kadar air pada produk perikanan. Adapun perhitungan kadar air yang dapat dihitung pada persamaan (1) sebagai berikut :

$$
\text { Kadar air }=\frac{(B-C)}{(B-A)} \times 100 \%
$$

Keterangan :

$\mathrm{A}=$ Berat kering cawan (gr)

$\mathrm{B}=$ Berat kering cawan dan sampel awal (gr) 
$\mathrm{C}=$ Berat kering cawan dan sampel setelah ikan dikeringkan (gr).

\section{2) Persentase Error}

Persentase error merupakan suatu angka yang dinyatakan dalam bentuk satuan persen $\%$. Perhitungan persentase error digunakan untuk mengetahui nilai persentase error antara nilai sensor dengan nilai alat ukur pembanding. Pada penelitian ini perhitungan persentase error dilakukan terhadap sensor suhu DS18B20 dan sensor massa loadcell. Perhitungan persentase error dapat dilihat pada rumus berikut [10].

Persentase error :

$$
=\frac{\text { Nilai sensor-Nilai alat ukur }}{\text { Nilai alat ukur }} \times
$$

$100 \%$

\section{Metode Penelitian}

Paragraf harus teratur. Semua paragraf harus rata, yaitu sama-sama rata kiri dan dan rata kanan.

\section{A. Metode Penelitian}

1) Studi Literatur: Metode studi literatur dilakukan dengan mencari referensi dari kajian terdahulu yang menjadi dasar penelitian dan buku serta jurnal-jurnal yang berkaitan dengan perancangan pada penelitian ini. Studi literatur dilakukan juga untuk memahami secara teoritis yang berkaitan dengan perangkat penghitung kadar air pada ikan dengan memanfaatkan sensor massa untuk mengukur massa pada ikan.

2) Observasi: Metode observasi dilakukan dengan meninjau langsung kelapangan tentang permasalahan-permasalahan yang berkaitan dengan proses pengeringan ikan pada kondisi sebenarnya.

3) Perancangan: Metode perancangan dilakukan dengan perancangan sensor suhu DS18B20, perancangan sensor massa loadcell, perancangan keypad, perancangan LCD, perancangan relay, dan perancangan mekanik pada perangkat.

4) Pengujian: Metode pengujian dilakukan untuk mendapatkan data melalui perangkat yang telah dirancang.

\section{B. Perancangan Sistem}

Perancangan sistem terbagi atas 3 bagian yaitu bagian input terdiri dari sensor massa loadcell, sensor suhu DS18B20, keypad, bagian proses terdiri dari Arduino Mega 2560 dan output terdiri dari relay, LCD, pemanas, kipas pendingin.

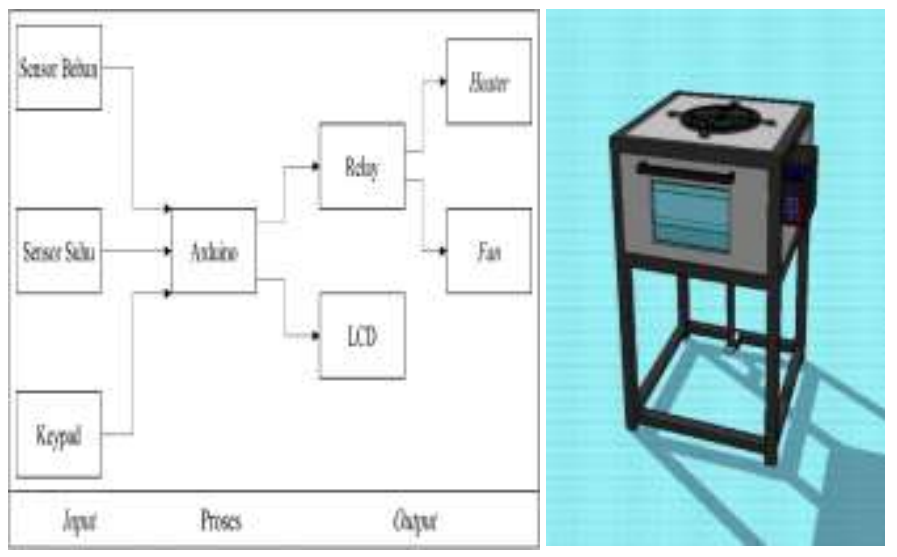

Gambar 1. Blok diagram dan design

Selain bagian utama, perangkat ini terdapat pula perangkat keras penunjang yaitu adaptor dan step down, perangkat tersebut memiliki fungsi khusus untuk mengoptimalkan kerja sistem pada perangkat yang telah dirancang.

\section{Cara Kerja Perangkat}

Cara kerja perangkat penelitian ini dimulai dengan menginisialisasi port mikrokontroler Arduino, kemudian mikrokontroler akan melakukan proses pembacaan parameter pada sensor suhu dan massa yang telah terhubung dengan Arduino Mega 2560. Mikrokontroler akan selalu membaca sensor selama alat dijalankan dan hasil pembacaan sensor akan di tampilkan pada LCD. Nilai dari pembacaan sensor akan digunakan untuk mengontrol kipas pendingin dan pemanas pada kabinet.

Hasil dari pembacaan sensor suhu DS18B20 digunakan untuk mengontrol kipas pendingin dan pemanas pada saat proses pengeringan ikan berjalan. 


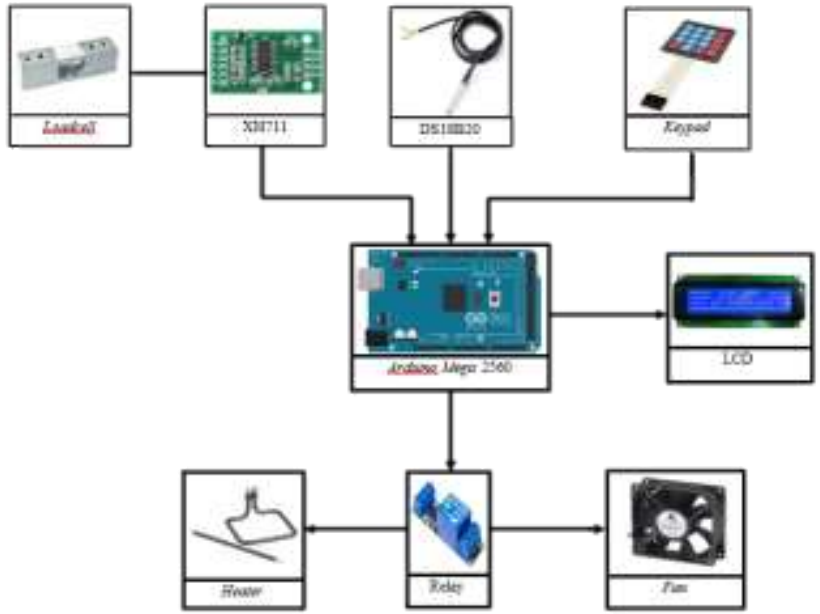

Gambar 2. Perancangan perangkat keseluruhan

Ketika suhu lebih besar dari $60^{\circ} \mathrm{C}$ dengan kadar air pada ikan kurang dari $40 \%$ maka kipas pendingin akan aktif untuk mengeluarkan suhu panas pada pengeringan ikan dan pemanas tidak aktif. Ketika suhu kurang dari $60^{\circ} \mathrm{C}$ dengan kadar air pada ikan lebih dari $40 \%$ maka kipas pendingin tidak aktif dan pemanas aktif untuk mengurangi kadar air pada ikan.

Perangkat pada penelitian ini menggunakan dua sensor yaitu sensor suhu DS18B20 dan sensor massa loadcell sebagai input sistem yang akan diolah oleh mikrokontroler Arduino Mega 2560 dan hasil pengolahan akan ditampilkan pada LCD 20x4.

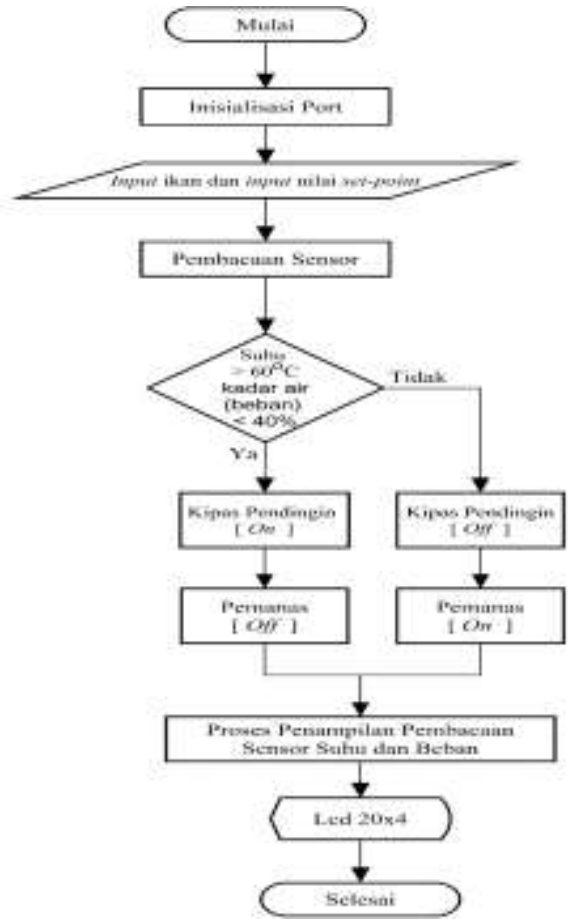

Gambar 3. Diagram alir perangkat

\section{Pengujian Sistem dan Analisis}

A. Pengujian Arduino Mega 2560

Pengujian Arduino dilakukan untuk mengetahui apakah source code program yang digunakan pada Arduino dapat memproses data hasil pembacaan sensor bekerja dengan baik.

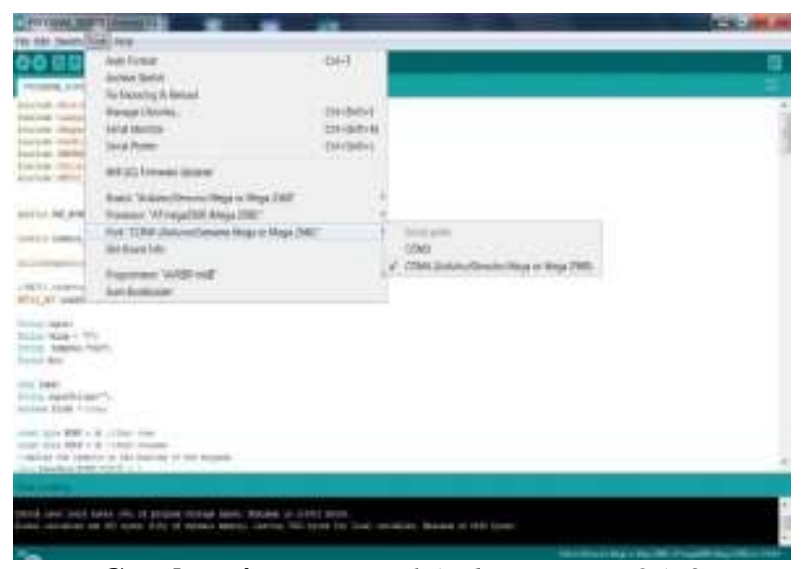

Gambar 4. Port serial Arduino mega 2560

Sebelum meng-upload program keseluruhan ke Arduino, terlebih dahulu harus menentukan Board dan Port yang digunakan pada perangkat lunak Arduino. Pada pengujian ini menggunakan pilihan Board Arduino Mega 2560 dan Port COM4. Hal ini dilakukan agar perangkat lunak Arduino dapat mendeteksi jenis Arduino yang digunakan.

Berdasarkan hasil pengujian pada perangkat lunak Arduino, program berhasil di upload ke perangkat keras Arduino selama 20 detik. Lamanya proses upload dipengaruhi oleh besarnya data yang akan di upload. Perubahan nilai pembacaan sensor yang akan dikirimkan pada LCD membutuhkan delay (waktu jedah) sekitar 0,5 detik. Respon Arduino terhadap relay dan indikator relay sekitar 0,3 detik. Hal tersebut sesuai dengan program yang dibuat. Dalam menampilkan nilai pembacaan sensor ke LCD berjalan lancar tanpa adanya tambahan waktu.

Pengujian Arduino Mega 2560 menggunakan salah satu sensor loadcell yang berfungsi untuk menguji Arduino Mega 2560 bisa berkerja dengan baik atau tidak. Multimeter digital digunakan untuk mengukur tegangan pada Arduino Mega 2560 sehingga dapat diketahui berapa tegangan yang diterima dari sensor loadcell dan tegangan dari Arduino Mega 2560 yang cukup untuk menjalankan sensor load 
R. Pramana, K. Ilham, S.Nugraha, M. Otong, dan D. Aribowo, Perancangan Perangkat Pengerikan Ikan Otomatis Skala Mini

cell dengan baik. Berikut pin sensor dan komponen yang dibungkan ke Arduino Mega 2560 .

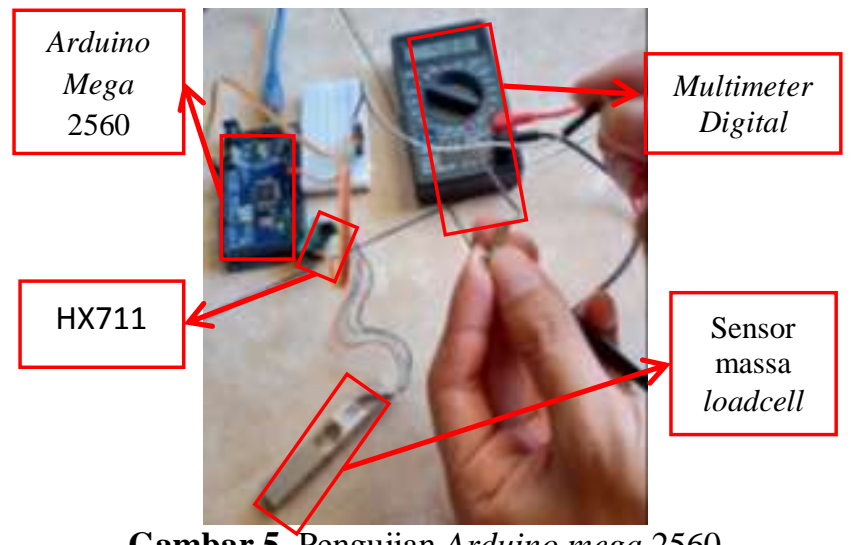

Gambar 5. Pengujian Arduino mega 2560

Tabel 1. Pin sensor dan komponen yang terhubung dengan Arduino mega 2560

\begin{tabular}{|c|c|c|c|}
\hline No & $\begin{array}{l}\text { Sensor dan } \\
\text { Komponen }\end{array}$ & Pin Sensor & $\begin{array}{c}\text { Pin } \\
\text { Arduino } \\
\text { Mega } 2560\end{array}$ \\
\hline \multirow[t]{3}{*}{1} & Sensor suhu & $\mathrm{VCC}$ & $5 \mathrm{~V}$ \\
\hline & DS18B20 & Data & 4 \\
\hline & & GND & GND \\
\hline \multirow[t]{4}{*}{2} & Sensor massa & VCC & $5 \mathrm{~V}$ \\
\hline & loadcell & SCK & 2 \\
\hline & & DT & 3 \\
\hline & & GND & GND \\
\hline \multirow[t]{8}{*}{3} & Keypad & Row 1 & 13 \\
\hline & & Row 2 & 12 \\
\hline & & Row 3 & 11 \\
\hline & & Row 4 & 10 \\
\hline & & Column 1 & 9 \\
\hline & & Column 2 & 8 \\
\hline & & Column 3 & 7 \\
\hline & & Column 4 & 6 \\
\hline \multirow[t]{4}{*}{4} & LCD I2C & VCC & $5 \mathrm{~V}$ \\
\hline & & SCL & SCL \\
\hline & & SDA & SDA \\
\hline & & GND & GNd \\
\hline \multirow[t]{4}{*}{5} & Relay 2 channel & VCC & $3,3 \mathrm{~V}$ \\
\hline & & IN 1 & 53 \\
\hline & & IN 2 & 52 \\
\hline & & GND & GND \\
\hline
\end{tabular}

Berdasarkan tabel 1, pin dari sensor dan komponen dapat dihubungkan ke Arduino Mega 2560. Pin yang terhubung dari sensor dan komponen ke Arduino Mega 2560 dapat bekerja dengan baik.

\section{B. Pengujian Sensor Suhu DS18B20}

Sensor suhu DS18B20 berfungsi untuk mendekteksi suhu pada pada ruang kabinet pengeringan ikan. Pembacaan sensor suhu DS18B20 akan di proses oleh Arduino Mega 2560 dan Output dari sensor suhu DS18B20 akan mengendalikan pemanas dan kipas pendingin melalui relay. Pengujian sensor suhu ini dilakukan untuk mengetahui apakah sensor dapat bekerja dengan baik dan sesuai perancangan yang telah dibuat.

Perangkat pembanding sensor suhu dilakukan dengan menggunakan thermometer digital. Untuk mengetahui ketepatan pembacaan suhu, maka nilai dari pembacaan sensor suhu DS18B20 dibandingkan dengan nilai pembacaan thermometer digital dalam rentang waktu yang sama. Hasil dari pengujian nilai sensor suhu DS18B20 dengan alat ukur thermometer secara visual dapat dilihat pada gambar 6 .

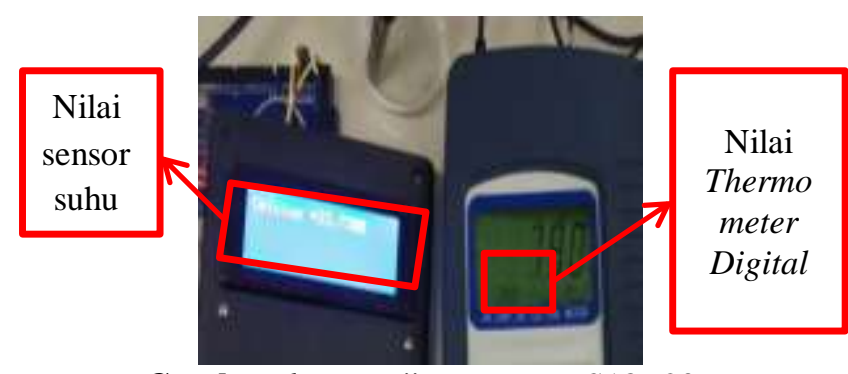

Gambar 6. Pengujian sensor DS18B20

Berdasarkan gambar 6, pada pengujian yang dilakukan pengukuran suhu dari thermometer lebih tinggi dibanding dengan pengukuran sensor suhu DS18B20. Pengukuran suhu pada sensor dengan alat ukur pembanding terjadi persentase error. Berikut adalah grafik hasil pengujian pembanding antara thermometer dan sensor suhu DS18B20.

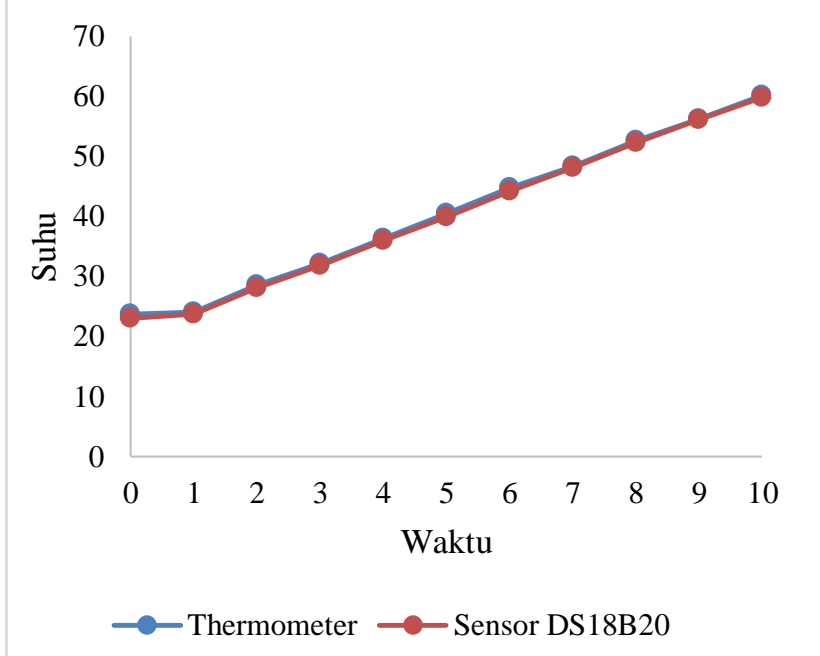

Gambar 7. Grafik pengujian sensor suhu DS18B20 
Berdasarkan gambar 7 , pengambilan data pengukuran pada suhu ruangan diambil setiap 1 menit selama 10 menit. Pembacaan dari sensor DS18B20 akan ditampilkan pada LCD. Berdasarkan dari hasil pengujian yang didapat bahwa pengukuran sensor suhu DS18B20 tidak sama dengan alat thermometer digital disebabkan oleh adanya persentase error, sehingga pengukuran suhu pada sensor tidak sama dengan alat thermometer digital. Perhitungan persentase error:

Persentase error $=\frac{23,01-23,7}{23,7} \times 100 \%$

Persentase error $=2,91 \%$

Dari perhitungan persamaan

(2) nilai persentase yang didapatkan, bahwa kesalahan error pada pembacaan sensor suhu DS18B20 dengan nilai alat ukur thermometer digital didapatkan persentase kesalahan $0,28 \%$ hingga 2,91\%. Tingkat kesalahan antara sensor suhu DS18B20 dengan alat ukur thermometer digital memiliki error yang kecil. Pengujian ini membuktikan bahwa sensor suhu DS18B20 dapat berjalan dengan baik.

\section{Pengujian Sensor Massa Loadcell}

Pengujian sensor massa loadcell bertujuan untuk mengukur massa pada ikan. Pembacaan sensor massa loadcell akan di proses oleh Arduino Mega 2560 dan sensor massa loadcell akan mengendalikan pemanas dan kipas pendingin melalui relay. Pengujian sensor massa ini dilakukan untuk mengetahui apakah sensor dapat bekerja dengan baik dan sesuai perancangan yang telah dibuat. Perangkat pembanding sensor massa loadcell dilakukan dengan menggunakan timbangan digital. Pengujian sensor massa loadcell dilakukan pada saat tidak dalam proses pengeringan ikan. Hasil dari pengujian nilai sensor loadcell dengan timbangan digital secara visual dapat dilihat pada gambar 8 .

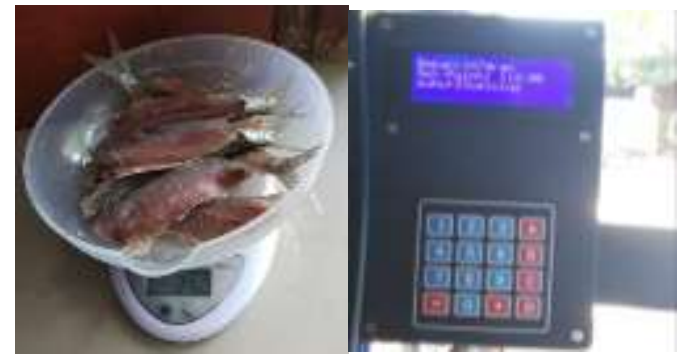

Gambar 8. Pengujian sensor loadcell
Berdasarkan gambar 8, berdasarkan hasil pengujian nilai pembanding antara timbangan digital dengan sensor tidak sama. Nilai pengukuran terhadap sensor dengan timbangan digital terjadi kesalahan error sehingga nilai yang terukur pada sensor memiliki selisih dengan hasil pengukuran dari timbangan digital. Berikut adalah grafik hasil pengujian pembanding antara timbangan digital dengan sensor massa loadcell.

Tabel 2. Hasil data pengujian sensor massa loadcell dengan timbangan digital

\begin{tabular}{cccc}
\hline No & $\begin{array}{c}\text { Timbangan } \\
\text { digital }(\mathbf{g})\end{array}$ & $\begin{array}{c}\text { Sensor massa } \\
\text { loadcell }(\mathbf{g})\end{array}$ & $\begin{array}{c}\text { Error } \\
(\boldsymbol{\%})\end{array}$ \\
\hline 1 & 250 & 247 & 1,2 \\
2 & 500 & 497 & 0,6 \\
3 & 1000 & 997 & 0,3 \\
\hline
\end{tabular}

1200

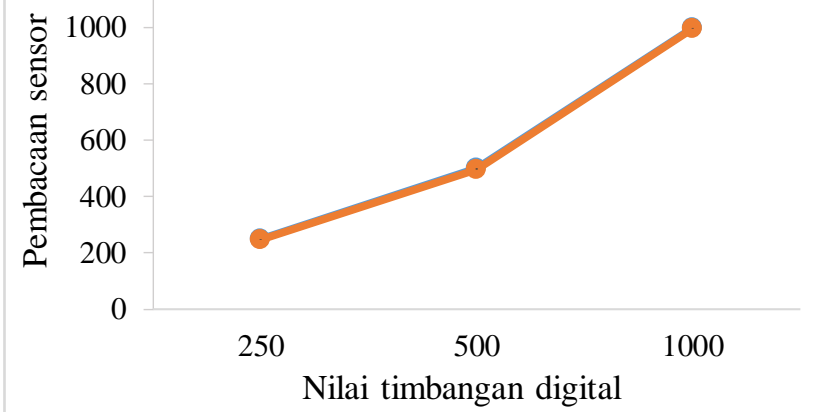

-Timbangan digital $\quad-$ Sensor beban loadcell

Gambar 9. Grafik pengujian sensor massa loadcell

Pada gambar 9, pengujian sensor massa loadcell dilakukan dengan mengukur massa pada ikan sebesar 250g, 500g, dan 1000g. Massa ikan ditimbang oleh sensor massa loadcell dan timbangan digital sebagai nilai pembanding. Berdasarkan dari hasil pengujian yang didapat bahwa pengukuran sensor massa loadcell tidak sama dengan alat timbangan digital dengan persentase error didapat dengan menggunakan persamaan (2).

Persentase error $=\frac{247-250}{250} \times 100 \%$

Persentase error $=1,2 \%$

Dari hasil pengujian yang dapat dilihat bahwa grafik dari nilai pembacaan perangkat sensor massa loadcell dengan nilai timbangan digital tidak sama dan memiliki selisih yang kecil sebesar $3 \mathrm{~g}$ dengan nilai persentase kesalahan $0,3 \%$ hingga $1,2 \%$. Persentase error yang kecil ini membuktikan bahwa sensor massa loadcell dapat berjalan dengan baik. 


\section{Pengujian Keypad}

Keypad yang digunakan adalah keypad $4 \times 4$. Pengujian perangkat keypad bertujuan untuk mengetahui apakah perangkat dapat bekerja dengan baik dan sesuai perancangan yang telah dibuat. Berikut adalah gambar pengujian keypad.

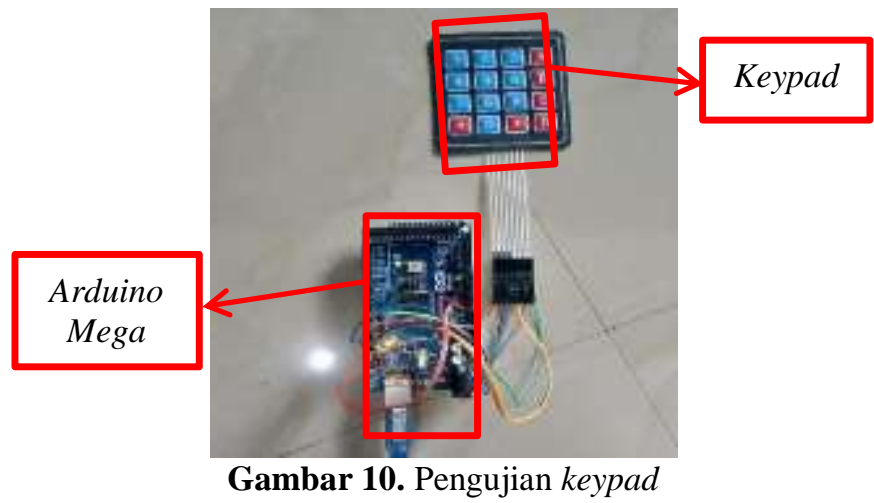

Pada gambar 9, keypad diuji menggunakan Arduino Mega 2560. Arduino Mega 2560 berfungsi sebagai pengolah data untuk mengupload program yang akan menjalankan fungsi dari keypad. Program dasar dari keypad akan di upload dari Arduino Mega 2560 untuk mengetahui apakah keypad bisa digunakan dengan baik atau tidak. Berikut adalah hasil dari pengujian keypad yang terdapat pada tabel 3 .

Tabel 3. Hasil pengujian keypad

\begin{tabular}{|c|c|c|}
\hline No & $\begin{array}{l}\text { Input Nilai } \\
\text { Pada Keypad }\end{array}$ & $\begin{array}{c}\text { Output Pada } \\
\text { LCD }\end{array}$ \\
\hline 1 & 0 & “ 0 " \\
\hline 2 & 1 & "1" \\
\hline 3 & 2 & "2" \\
\hline 4 & 3 & "3" \\
\hline 5 & 4 & "4" \\
\hline 6 & 5 & "5" \\
\hline 7 & 6 & “6” \\
\hline 8 & 7 & “7” \\
\hline 9 & 8 & "8" \\
\hline 10 & 9 & "9" \\
\hline 11 & $*$ & “*” \\
\hline 12 & \# & “"\#” \\
\hline 13 & A & "A" \\
\hline 14 & B & "B” \\
\hline 15 & $\mathrm{C}$ & "C"C" \\
\hline 16 & $\mathrm{D}$ & "D" \\
\hline
\end{tabular}

Berdasarkan hasil pengujian pada tabel 3, nilai output yang ditampilkan oleh LCD sesuai dengan nilai yang telah di input dari keypad. Perangkat tidak ada kendala untuk meng-input nilai dari keypad. Pengujian ini membuktikan bahwa perangkat keypad dapat berjalan dengan baik.

\section{E. Pengujian $L C D$}

LCD pada perangkat berfungsi untuk menampilkan nilai suhu, massa dan setpoint massa. Input dari pembacaan nilai sensor suhu DS18B20, sensor loadcell, dan keypad yang telah di proses oleh Arduino Mega 2560 lalu output dari Arduino LCD akan menampilkan nilai suhu, nilai massa, dan nilai setpoint. Pengujian dilakukan untuk mengetahui apakah kolom dan baris pada LCD dapat bekerja dengan baik. Berikut bentuk visual dari hasil pengujian LCD.

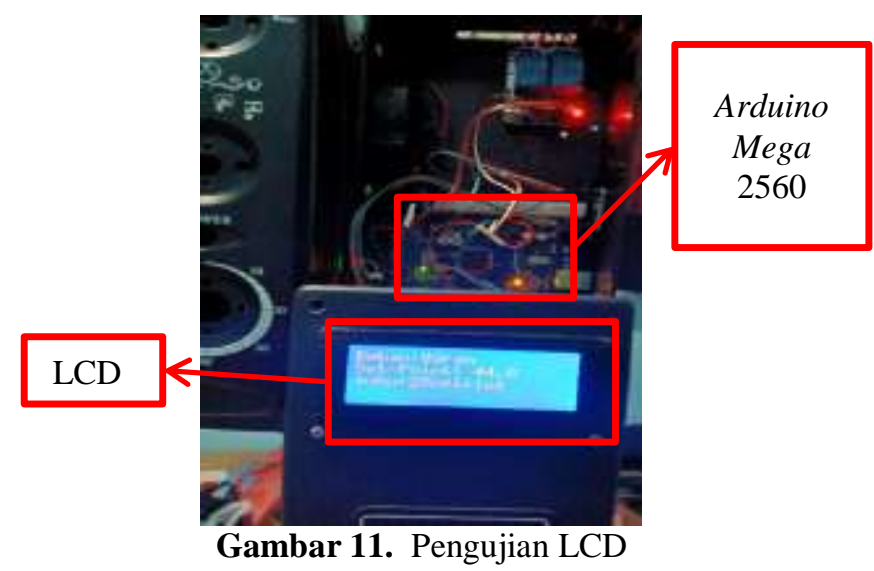

Pada gambar 11, pengujian dilakukan dengan kondisi sebenarnya dimana Arduino Mega 2560 mengolah data dan menampilkan hasilnya pada LCD sebagai display. LCD menampilkan nilai massa, nilai suhu, dan nilai setpoint secara real time hasil pembacaan dari sensor maupun keypad.

\section{F. Pengujian relay}

Pengujian relay dilakukan untuk mengetahui apakah relay bisa mengontrol elemen pemanas dan kipas pendingin. Pada pengujian relay Arduino Mega 2560 berfungsi untuk mengolah data yang bertujuan agar relay dapat mengontrol elemen pemanas dan kipas pendingin. Visual pengujian relay dapat dilihat pada gambar 12 . 


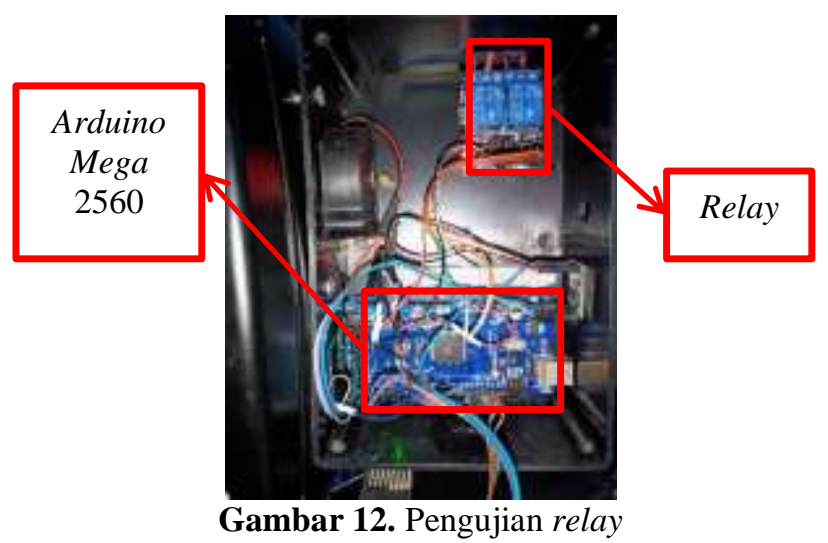

Berdasarkan gambar 12, pengujian dilakukan dengan menggunakan Arduino Mega 2560 sebagai pengolah data untuk memberikan program perintah pada relay. Output pada relay akan dihubungkan ke elemen pemanas dan kipas pendingin. Berikut Tabel hasil pengujian relay dengan sensor suhu DS18B20.

Tabel 4. Pengujian relay dengan sensor suhu DS18B20

\begin{tabular}{cccccc}
\hline & \multirow{2}{*}{ No } & $\begin{array}{c}\text { Suhu } \\
\left({ }^{\circ} \mathbf{C}\right)\end{array}$ & Aktif & $\begin{array}{c}\text { Kipas pendingin } \\
\text { aktif }\end{array}$ & \multicolumn{2}{c}{ Elemen pemanas } \\
\hline 1 & 59 & & $\sqrt{ }$ & $\sqrt{ }$ & $\begin{array}{c}\text { Tidak } \\
\text { aktif }\end{array}$ \\
2 & 60 & $\sqrt{ }$ & & & $\sqrt{ }$ \\
3 & 61 & $\sqrt{ }$ & & & $\sqrt{ }$ \\
4 & 62 & $\sqrt{ }$ & & & $\sqrt{ }$ \\
\hline
\end{tabular}

Pada tabel 4, pengujian relay dihubungkan dengan sensor suhu DS18B20 yang berfungsi untuk mengatur suhu pada proses pengeringan ikan. Arduino Mega 2560 berguna untuk mengolah data yang akan mengatur relay untuk mengontrol fungsi kerja dari sensor suhu DS18B20. Ketika suhu kurang dari $60^{\circ} \mathrm{C}$ kipas pendingin tidak aktif dan pemanas aktif, ketika suhu lebih dari $60^{\circ} \mathrm{C}$ kipas pendingin aktif dan pemanas tidak aktif. Hasil dari pengujian relay yang dihubungkan dengan sensor suhu DS18B20 dapat bekerja dengan baik. Berikut Tabel pengujian relay dihubungkan dengan sensor massa loadcell.

Tabel 5. Pengujian relay dengan sensor massa loadcell

\begin{tabular}{cccccc}
\hline & Massa & \multicolumn{2}{c}{ Kipas pendingin } & \multicolumn{2}{c}{ Elemen pemanas } \\
\cline { 4 - 6 } No & $($ g) & Aktif & $\begin{array}{c}\text { Tidak } \\
\text { aktif }\end{array}$ & Aktif & $\begin{array}{c}\text { Tidak } \\
\text { aktif }\end{array}$ \\
\hline 1 & 250 & & $\sqrt{ }$ & $\sqrt{ }$ & \\
2 & 100 & $\sqrt{ }$ & & & $\sqrt{ }$ \\
\hline
\end{tabular}

Pada tabel 5, pengujian relay dihubungkan dengan sensor massa loadcell. Arduino Mega 2560 berfungsi untuk mengolah data yang akan mengatur relay untuk mengontrol kadar air dan massa ikan pada proses pengeringan ikan. Pada tabel 5 massa awal ikan sebesar $250 \mathrm{~g}$ maka kondisi kipas pendingin tidak aktif dan pemanas aktif. Pemanas akan aktif bekerja selama nilai massa ikan belum mencapai nilai set point yang telah di input pada keypad dengan nilai $100 \mathrm{~g}$. Pada saat nilai massa sudah mencapai nilai set point, maka heater otomatis tidak aktif dan kipas pendingin akan aktif untuk mengeluarkan suhu pada ruang kabinet pengering ikan. Hasil dari pengujian ini relay dapat bekerja dengan baik.

Tabel 6. Hasil pengujian

\begin{tabular}{cccccc}
\hline & \multicolumn{2}{c}{$\begin{array}{c}\text { Massa } \\
(\mathbf{g})\end{array}$} & \multicolumn{2}{c}{$\begin{array}{c}\text { Kadar Air } \\
(\boldsymbol{\%})\end{array}$} & $\begin{array}{c}\text { Waktu (Lama } \\
\text { Pengeringan) }\end{array}$ \\
\cline { 2 - 5 } & $\mathbf{A}$ & $\mathbf{B}$ & $\mathbf{A}$ & $\mathbf{B}$ & \\
\hline 1 & 250 & 100 & 100 & 40 & 1 jam 43 menit \\
2 & 500 & 200 & 100 & 40 & 3 jam 17 menit \\
3 & 1000 & 400 & 100 & 40 & 6 jam 25 menit \\
\hline
\end{tabular}

Keterangan :

A = Awal

$\mathrm{B}=$ Akhir

Berdasarkan hasil pengujian yang dilakukan dengan 3 massa ikan sebesar 250g, 500g, dan $1000 \mathrm{~g}$ membutuhkan waktu 1 jam 43 menit hingga 6 jam 25 menit. Kondisi awal kadar air pada ikan sebesar 100\% dapat berkurang hingga tersisa $40 \%$ sesuai Standar Nasional Indonesia, dengan proses pengeringan ikan menggunakan sensor suhu DS18B20 sebagai pendeteksi suhu pada ruang kabinet dan sensor loadcell sebagai pendeteksi massa atau kadar air pada ikan. Heater sebagai pengurang kadar air atau massa pada ikan dan kipas pendingin untuk membuang suhu panas pada ruang kabinet pengering ikan dikontrol oleh relay yang terprogram pada Arduino Mega 2560.

Hasil pengujian perangkat pengontrol kadar air pada ikan dengan massa awal $250 \mathrm{~g}$ menghasilkan massa ikan sebesar 100g. Untuk mengetahui sisa kadar air yang terdapat pada ikan dengan cara perhitungan berdasarkan Standar Nasional Indonesia [9], berikut perhitungan kadar air dengan persamaan (1) :

Kadar air $=\frac{(\mathrm{B}-\mathrm{C})}{(\mathrm{B}-\mathrm{A})} \times 100 \%$

Diketahui : $\mathrm{A}=125 \mathrm{~g}$

$$
B=125 \mathrm{~g}+250=375 \mathrm{~g}
$$


R. Pramana, K. Ilham, S.Nugraha, M. Otong, dan D. Aribowo, Perancangan Perangkat Pengerikan Ikan Otomatis Skala Mini

$$
\mathrm{C}=125 \mathrm{~g}+100 \mathrm{~g}=225 \mathrm{~g}
$$

Ditanya : Berapa sisa kadar air yang terdapat pada ikan?

$$
\begin{aligned}
& =\frac{((125 \mathrm{~g}+250 \mathrm{~g})-(125 \mathrm{~g}+100 \mathrm{~g}))}{((125 \mathrm{~g}+250 \mathrm{~g})-125 \mathrm{~g})} \times 100 \% \\
& =\frac{375 \mathrm{~g}-225 \mathrm{~g}}{375 \mathrm{~g}-125 \mathrm{~g}} \times 100 \% \\
& =\frac{150 \mathrm{~g}}{250 \mathrm{~g}} \times 100 \% \\
& =0,6 \times 100 \%=60 \% \\
& =100 \%-60 \%
\end{aligned}
$$

Kadar air $=40 \%$

Hasil analisis perhitungan kadar air pada ikan memiliki $40 \%$ kadar air yang tersisa pada ikan. Kadar air pada ikan 250g yang dikeringkan oleh perangkat juga sama sebesar $40 \%$. Nilai kadar air pada ikan tersebut sesuai dengan ketentuan Standar Nasional Indonesia yaitu $40 \%$.

\section{KESIMPULAN}

Hasil penelitian yang telah dilakukan dapat disimpulkan sebagai berikut: Perangkat yang telah dirancang dapat mengontrol kadar air pada ikan yang ingin dikeringkan sesuai standar kadar air ikan kering melalui nilai yang di input dari keypad. Perangkat sistem kontrol kadar air pada ikan menggunakan Arduino Mega 2560 sebagai komponen utama yang akan mengontrol sensor suhu DS18B20, sensor massa loadcell, keypad, LCD, relay, dan kipas pendingin. Perangkat ini dapat mengontrol pemanas dan kipas pendingin menggunakan relay ketika suhu kurang dari $60^{\circ} \mathrm{C}$ maka pemanas aktif dan kipas pendingin tidak aktif, ketika suhu lebih dari $60^{\circ} \mathrm{C}$ maka pemanas tidak aktif dan kipas pendingin aktif. Perangkat memiliki kapasitas maksimal massa ikan yang dikeringkan sebesar $1000 \mathrm{~g}$ dengan jangka waktu pengeringan 6 jam 25 menit.

\section{UCAPAN TERIMA KASIH}

Puji syukur peneliti kepada Allah SWT atas Rahmat dan Karunia yang diberikan-NYA. Juga terimakasih kepada redaktur, reviewer dan editor Jurnal Sustainable atas kerja kerasnya membantu publikasi jurnal ini.

\section{REFERENSI}

[1] Bintang, Y.M., Pongoh, J., Onibala, H., 2013, Konstruksi Dan Kapasitas Alat
Pengering Ikan Tenaga Surya Sistem Bongkar Pasang, Jurnal Media Teknologi Perikanan, Volume 1 (Nomor 2), Halaman 40.

[2] Badan Standardisasi Nasional. 1992. Standard Nasional Indonesia-SNI 01-27211992: Ikan asin kering. BSN. Jakarta.

[3] Simanjuntak, A.P., Pramana, R., 2013, Pengontrolan Suhu Air Pada Kolam Pendederan Dan Pembenihan Ikan Nila Berbasis Arduino, Jurnal Sustainable, Volume 4 (Nomor 1), ISSN 2087-5347.

[4] Tuyu, A., Onibala, H., Makapedua, D.M., 2014, Studi Lama Pengeringan Ikan Selar (Selaroides sp), Jurnal Media Teknologi Hasil Perikanan, Volume 2 (Nomor 2), Halaman 20-26.

[5] Budiawan, R.A., Wendanto, W., 2015, Alat Pengering dan Pengukur Kadar Air Pada Gabah Berbasis Mikrokontroler, Jurnal Informatika, Volume 2 (Nomor 1), ISSN 2337 - 5213 Halaman 55-63.

[6] Hidayat, R., 2016, Pengembangan Alat Pengukur Kadar Air Padi (Gabah) Untuk Mewujudkan Pertanian Industrial Di Kabupaten Indramayu, CR Journal, Volume 2 (Nomor 1), Halaman 55-68.

[7] Saragih, F.F., Pramana. R., 2017, Perancangan Perangkat Prototype Pengasapan Ikan Dengan Pengontrolan Suhu, Repository UMRAH, Universitas Maritim Raja Ali Haji, Tanjungpinang.

[8] Kelana, A.R., Pramana, R., Nusyirwan, D., 2017, Perancangan Perangkat Pengering Ikan Otomatis Berbasis Arduino uno Dengan Sumber Daya Mandiri, Repository UMRAH, Universitas Maritim Raja Ali Haji, Tanjungpinang.

[9] Badan Standardisasi Nasional. 2006. Standard Nasional Indonesia-SNI 012354.2-2006: Penentuan kadar air pada produk perikanan. BSN. Jakarta.

[10]Anwar, M.D., Hadiyanto, G.T., Ismunandiri., 2016, Rancang Bangun Sistem Alarm Dengan Multisensor Dan Monitoring ke personal Computer (PC), Zona Elektro, Volume 6 (Nomor 3), Halaman 10. 